\title{
POR UMA HISTÓRIA DO NEGRO NO SUL DO MATO GROSSO: história oral de quilombolas de Mato Grosso do Sul e a (re)invenção da tradição africana no cerrado brasileiro
}

Lourival dos Santos*

RESUMO: No Mato Grosso do Sul, a questão da identidade quilombola opôs o Instituto Histórico e Geográfico do estado e a Fundação Palmares. O primeiro emitiu parecer, em 2008, afirmando não reconhecer a presença de qualquer núcleo remanescente quilombola no estado. A segunda certificou 22 comunidades como sendo de remanescentes quilombolas até 2017. Esse artigo propõe uma nova narrativa para a História do negro na região, em diálogo com as comunidades e o conhecimento acadêmico com o potencial de reescrevermos a história dos negros no sul do antigo Mato Grosso, deslocando-os da posição de subordinados para a de protagonistas no processo de ocupação do oeste do Brasil com implicações na definição de políticas públicas de atendimento a essas comunidades, em conflito com outros interesses políticos e econômicos.

PALAVRAS CHAVE: Identidade negra; Comunidades quilombolas; Mato Grosso do Sul.

\section{History of black people in south of Mato Grosso: the oral histories of maroons in Mato Grosso do Sul and the (re)invention of African traditions in the brazilian cerrado}

ABSTRACT: In the Brazilian state of Mato Grosso do Sul, the question of maroon identity has served as a point of contention between the state's Historical and Geographical Institute and the Palmares Foundation. The former issued a resolution in 2008, stating that they do not recognize the presence of any remaining maroon-descendent community in the state. The latter recognized 22 distinct maroondescendent communities in 2017. This article proposes a new narrative for black history, in dialogue with maroon communities and with academic knowledge, that has the potential to rewrite the history of African descendants in the region. Such an approach places what were once subordinates as the protagonists of the process of settling the Brazilian west and has implications on the definition of public service policies for these communities, in conflict with other political and economic interests.

KEY WORDS: Black identity; Maroon communities; Mato Grosso do Sul.

\section{Por una historia del negro en el sur de Mato Grosso: historia oral de quilombolas de Mato Grosso do Sul y la (re)invención de la tradición africana en el cerrado brasileño}

RESUMEN: En Mato Grosso do Sul, la cuestión de la identidad quilombola opuso el Instituto Histórico y Geográfico del estado y la Fundación Palmares. El primero emitió parecer, en 2008, afirmando no reconocer la presencia de cualquier núcleo remaneciente quilombola en el estado. La segunda certificó 22 comunidades como siendo de remanecientes quilombolas hasta 2017. Ese artículo propone una nueva narrativa para la Historia del negro en la región, en dialogo con las comunidades y el conocimiento académico con el potencial de reescribirnos la historia de los negros en la región, dislocando a ellos de la posición de subordinados para la de protagonistas en el proceso de ocupación del oeste de Brasil con implicaciones en la definición de políticas públicas de atendimiento a esas comunidades, en conflicto con otros intereses políticos y económicos

PALABRAS CLAVE: Identidad negra; Comunidades quilombolas; Mato Grosso do Sul.

\footnotetext{
*Doutor em História Social pela Universidade de São Paulo (USP). Historiador e atualmente Professor Associado da Faculdade de Educação da Universidade Federal de Mato Grosso do Sul (FAED/UFMS). Contato: Cidade Universitária Universitário - Pioneiros, CEP: 79070-900, Campo Grande - MS, Brasil. E-mail: lourival.santos@ufms.br.
} 


\section{História dos quilombos e dos quilombolas no Brasil}

Os quilombos e os quilombolas ocuparam a atenção de autoridades coloniais e imperiais dos séculos XVII ao XIX e de estudiosos durante todo o século XX. E a preocupação segue até os dias de hoje. O artigo 68 das disposições transitórias da Constituição de $1988^{1}$ consolidou uma demanda do movimento negro no Brasil ao redor do que Abdias do Nascimento chamou de Quilombismo ${ }^{2}$ e inaugurou para o movimento negro, antropólogos, juristas e historiadores uma nova senda de investigação: a dos novos quilombos. Nossa contribuição trata desses últimos no atual estado do Mato Grosso do Sul e pretende, por intermédio do uso da História Oral, ampliar as narrativas ao redor dessas comunidades e propor a escrita da história do negro nessa região do cerrado brasileiro.

Segundo Flávio dos Santos Gomes ${ }^{3}$, Bernardo Guimarães (autor de Escrava Isaura) escreveu História de quilombolas em 1871. O romance humanizava os quilombolas e desvelava elementos importantes para o conhecimento de aspectos da vida em sociedade nessas comunidades: as relações entre africanos, crioulos e forros, as várias conexões do quilombo com outras comunidades, suas razias e relações mercantis, bem como "acordos" com expedições punitivas. O romance registra a presença dos quilombos no imaginário dos leitores no final do século XIX.

Gomes enumera as formas de resistência e de protesto durante o período da escravidão e do pós-abolição: fugas, justiçamentos de feitores e senhores, revoltas nas fazendas, insurreições urbanas, quilombos, etc. e lembra que havia sociabilidades com enfrentamentos endêmicos, no cotidiano de senhores e escravos.

Segundo Gomes, os estudos sobre comunidades de escravos fugidos avançaram muito para as regiões do Caribe, bem diferente do que aconteceu no Brasil até pouco tempo atrás. Com a exceção de Palmares, ressaltada por seu gigantismo e longevidade, os quilombos apareceram na historiografia como protestos "uniformes" e "repetitivos" e, portanto, analisados como sem sentido político. Na historiografia brasileira o principal debate acerca da escravidão era saber se ela teria sido boa ou má, como resultado do aspecto patriarcal e paternalista das relações entre senhores e escravos. Gilberto Freyre teria dado a melhor forma para a benignidade do escravismo brasileiro. A questão teria ganhado fôlego estendendo-se aos estudos comparativos entre Brasil e Estados Unidos. No primeiro, onde vigoraria um sistema pré-capitalista católico, o paternalismo mediado pelo Estado e a Igreja teriam 
produzido cativos indolentes, preguiçosos, passivos e, acima de tudo, submissos a uma grande família patriarcal ${ }^{4}$.

Nos anos 1960 e 70 a temática ganhou fôlego na historiografia brasileira e as interpretações sobre o doce cativeiro passaram a ser questionadas. Começaram as ênfases no protesto escravo, caindo por terra as imagens de passividade e submissão. A escravidão passou a ser descrita como cruel e violenta, coisificando o escravo e suas organizações sociais, como suas famílias. Essa revisão historiográfica explicava a rebeldia escrava como reações ao caráter violento das relações sociais sob escravismo. Passou-se à uma visão romântica do protesto escravo e o binômio senhor cruel/escravo rebelde substituiu o binômio senhor camaradalescravo submisso. (Grifos de GOMES). Parte dessas interpretações, amparada em modelos teóricos cristalizados, reduziram os escravos à papel de figurantes, uma vez que coisificados pela crueldade e violências sistêmicas. Humanização, só quando conseguiam se revoltar, fugir e se refugiar nos quilombos. As fugas coletivas, as insurreições $e$ os quilombos foram vistos como formas quase que exclusivas denominadas generalizadamente de resistência e rebeldia ${ }^{5}$.

Para Gomes, diversos autores, desde 1930 procuraram analisar os quilombos no Brasil. Esses estudos, seguindo categorias usadas por João dos Reis a respeito de revoltas escravas na Bahia permitiram ao autor classificar as interpretações em duas correntes: culturalista e materialista. Na primeira estariam incluídos, seguindo a senda aberta por Nina Rodrigues: Arthur Ramos, Edison Carneiro, Roger Bastide entre outros.

[...]Nessas perspectivas culturalistas, quilombos representavam um fenômeno "contra-aculturativo", que tinha origem na "persistência da cultura africana", em resposta ao permanente processo de "aculturação" da sociedade escravista.

Segundo Gomes, Arthur Ramos afirmou que os escravizados do Novo Mundo passaram por um processo de "aculturação negra" em contraposição a adaptação à outras culturas, notadamente a branca. As perspectivas antropológicas de Ramos ganharam força nos anos 1930 e 40, particularmente suas abordagens sobre padrões de "cultura negra" no Brasil, influenciando diversos pesquisadores até os dias de hoje.

Quase paralelamente aos estudos de Ramos, surgiram as pesquisas de Edison Carneiro. Seu estudo pioneiro O Quilombo dos Palmares foi lançado em 1947 no Brasil e também manifestou preocupação com aspectos culturais africanos, em particular nas formas religiosas. Ele classificou os quilombos como fruto de um fenômeno "contra aculturativo", 
termo retomado e generalizado por Roger Bastide, ao investigar as religiões negras e que seria característica elementar de todas as comunidades de fugitivos forjadas nas Américas ${ }^{6}$.

Ainda segundo Gomes, essas análises mostravam uma concepção de cultura como algo estático e polarizado e desconsideravam os processos de reelaborações e invenções dessas comunidades, reduzindo todos os aspectos característicos dos quilombos ao conceito de resistência escrava e concluindo que as mesmas não ameaçavam o sistema escravista. Edison Carneiro concluiu pela "reafirmação dos valores das culturas africanas" ao passo que Bastide salientou que os quilombos seriam "ao mesmo tempo novas civilizações 'negras' $e$ civilizações 'africanas' arcaicas", .

A partir dos anos 1960 surgiram produções que enfatizaram o protesto escravo no debate historiográfico. Essa corrente interpretativa materialista incluía a perspectiva da luta de classes no debate sobre o escravismo no Brasil. O escravo dócil e indolente foi substituído pelo violento e rebelde exaltando-se a reação dos cativos. Essa nova abordagem enfatizou os quilombos "grandes" e "endêmicos" para valorizar seus líderes e seu suposto caráter revolucionário. Obra de referência dessa tendência é Rebeliões de Senzalas, de Clóvis Moura, publicado em 1959. Esse livro (e suas reedições de 1972,1981 e 1986) criticou a interpretação culturalista e se propunha a "restaurar a verdade histórica e social desfigurada por inúmeros estudiosos" a respeito dos quilombolas. Para Moura e outros autores que analisaram o protesto escravo na década de 1960 até o início dos anos 1980, o quilombo era inerente à escravidão e os quilombolas mesmo "sem conscientização" dinamizavam a estratificação social, uma vez que sua força de trabalho deixava de ser simples mercadoria podendo eles mesmos, vendê-la. Gomes reconhece a contribuição de Moura como fundamental em determinado momento político da história do Brasil, mas pondera que para esse autor as experiências eram quase que exteriores às ações dos sujeitos históricos que as vivenciavam havendo o escravo acomodado que aceitava a escravidão e o tipo rebelde, heroicizado que, entretanto, não tinha consciência social e criava, por meio de ações ativas e passivas, apenas "barreiras defensivas ao sistema" escravista. As atitudes de enfrentamento eram formas de luta sem ideologias e lógicas próprias. O sistema escravista teria ruído em função do seu "desgaste econômico" muito mais do que em função das ações de enfrentamento e das transformações na sociedade escravista. Gomes destaca que a obra de Moura e suas interpretações materialistas não foram levados adiantes nos estudos que se seguiram, a não ser pelo próprio autor. Em 1968, Luís Luna lançou O negro da luta contra a escravidão em que narrou episódios diversos da resistência escrava com destaque para os quilombos, as 
insurreições e o assassinatos, para demonstrar que os cativos não eram passivos diante da escravidão, pouco acrescentando ao ponto de vista de Moura acerca da reação ao sistema escravista.

Na década de 1970 novos trabalhos reavivaram o debate historiográfico sobre a escravidão. Destaque para as obras de José Alípio Goulart (1972) Da Fuga ao Suicídio. Aspectos da Rebeldia dos escravos no Brasil que, como Moura, criticava as interpretações culturalistas, porém sem acrescentar muito ao ponto de vista de que os protestos eram explicados pelo regime da escravidão, reações ao mesmo. A obra teve o mérito de oferecer uma visão panorâmica acerca dos quilombos no Brasil, valendo-se de documentação até então inédita - relatórios impressos dos presidentes e chefes de polícia no século XIX. Goulart transpareceu certo preconceito a propósito das culturas dos africanos na diáspora, ao mencionar "instintos primitivos" revigorados naqueles que fugiam para os quilombos que, libertos, passariam a agir como bichos, uma vez que como tais eram caçados ${ }^{8}$.

Décio Freitas ${ }^{9}$ ofereceu em meados dos anos 1970, ainda baseado em perspectiva materialista, análises inéditas sobre a Revolta dos Malês e o quilombo de Palmares. Sua obra explica que as revoltas escravas, apesar de causarem prejuízos ao regime escravocrata, deixavam-no intacto, sendo as verdadeiras razões de sua decadência as ações dos ingleses contra o tráfico negreiro. Salienta a debilidade dos escravos, enquanto classe social. [...] com esquemas cristalizados, definia o protesto escravo na perspectiva da subordinação aos modelos estruturais.

A corrente historiográfica pautada em análises materialistas teve grande importância política ao criticar as supostas benevolências da escravidão brasileira mas persistiu na ideia da "coisificação" de quilombolas e assenzalados ${ }^{10}$. O escravo não seria um sujeito, mas um guerreiro de uma lógica inexorável, com um único sentido histórico. Para Gomes, o escravo 'coisa passivo' da escola culturalista, cedia vez ao escravo 'coisa rebelde' da escola materialista, mantendo-o ambas, sob o prisma da "marginalização". Para os primeiros os escravos que fugiam para os quilombos reconstituiriam as origens africanas de sua cultura e para os segundos, tratavam-se de reação coletiva à escravidão. Assim, para as duas correntes, o aquilombamento aparecia como um processo que se dava praticamente fora da sociedade escravista em que os escravos resistiriam cultural e materialmente à dominação, só dessa maneira eles se tornariam sujeitos de sua própria história.

No final dos anos 1980 e nos anos 1990 novos estudos surgiram matizando o aspecto "marginal” dos quilombos. Em 1988 Carlos Magno Guimarães, retomava argumentos da 
escola materialista apontando o que chamou de "contradição" entre os quilombos mineiros no século XVIII, que estabeleciam relações econômicas e sociais com a sociedade circundante da época. Eurípedes Funes e João dos Reis trouxeram pesquisas mais inovadoras, organizando uma coletânea sobre a história dos quilombos no Brasil, em 1996.

Para Gomes:

Estudos contemporâneos sobre a escravidão e a pós-emancipação continuam abrindo novos caminhos para o entendimento mais complexo das relações entre senhores e escravos. Destacam-se pesquisas sobre família, campesinato negro, espaços de autonomia econômica dos cativos, cultura escrava, paternalismo, irmandades, alforrias, sociabilidades, controle social e violência no cotidiano do cativo ${ }^{11}$.

Em História de Quilombolas, Gomes pretende proceder à uma descrição densa dos documentos relativos à escravidão no Rio de Janeiro do século XIX, procurando escrever uma história dos quilombos a partir dos quilombolas, estabelecendo relações com os escravos das Senzalas e a sociedade envolvente da época. Em diálogo com a produção historiográfica a respeito da escravidão nos Estados Unidos e no Caribe consegue estabelecer diálogos que abrem pistas de investigação. Assim ele procura demonstrar que os quilombos são intrínsecos à própria sociedade escravocrata e suas ações contribuíram para a transformação das estruturas, fugindo dos esquematismos e das idealizações produzidas pelas duas correntes historiográficas que expulsavam os sujeitos da história da escravidão:

\begin{abstract}
$\mathrm{Na}$ tentativa de alargamento de horizontes teóricos procuramos analisar de que modo as vivências quilombolas produziram impactos nas relações entre senhores e escravos. Tentamos perscrutar os significados da cultura escrava, resgatando a historicidade das normas, valores e costumes, recuperando assim, a lógica das transformações. Procuramos escapar as armadilhas dos esquemas "marginalizantes apresentados na literatura clássica - sobre os quilombos brasileiros ${ }^{12}$.
\end{abstract}

Em A Hidra e os Pântanos, Flávio Gomes dos Santos nos lembra que a historiografia brasileira sempre privilegiou grandes quilombos e insurreições planejadas. Defende que aspectos históricos do protesto negro por serem complexos e multifacetados devem fugir de simplificações e polarizações. Sem negar a "coisificação" física dos escravos. Para Gomes os novos estudos devem superar a ideia de uma rebeldia escrava que procurava apenas 'reagir' a violência senhorial e debruçarem-se sobre as ações e seus significados. Pequenos mocambos ou rápidas revoltas passam a ter importância histórica ${ }^{13}$.

Tendo como referência essa nova produção historiográfica acerca dos quilombos contemporâneos, nosso trabalho envida esforços em dar ouvidos a sujeitos contemporâneos a partir de uma dinâmica própria da presença de ex-escravizados e seus descendentes em parte 
da região centro-oeste do Brasil. Procuramos por meio da História Oral, submetermo-nos às lógicas internas da formação dessas comunidades recorrendo ao paradigma indiciário de Carlo Ginzburg a partir do estabelecimento de uma história prospectiva ${ }^{14}$.

Nas narrativas que veremos adiante, podemos supor que os grupos de cativos que se aquilombaram no sul do antigo Mato Grosso pertenciam às mesmas localidades ou fazendas. Seguimos a mesma pista de Gomes: Os quilombos que constituíam vilas camponesas independentes possibilitaram, ao longo do tempo, a gestação de um campesinato negro ${ }^{15}$.

Os testemunhos que gravamos e as observações de campo indicam que o processo de fuga continuou no pós-abolição bem como o aquilombamento de negros formalmente libertos da escravidão. Essas evidências indicam a continuidade de um processo que surgiu com a exploração de mão escrava e segue até os dias de hoje, ensejando novas estratégias dos quilombolas de convívio com outros grupos sociais.

\section{O negro no sul do Mato Grosso.}

Entre 2012 e 2014, compus a equipe do Projeto de Pesquisa: Regularização Fundiária das Comunidades Quilombolas de MS - Levantamento bibliográfico e documental das políticas realizadas a partir de $2004^{16}$. Foi quando entrei em contato com as comunidades quilombolas do estado pela primeira vez. Em visitas de periodicidade mensal, eu era apresentado como o historiador do grupo e que estava lá para ouvir "causos". Dessa maneira, enquanto meus colegas antropólogos reuniam-se com líderes das comunidades em grupos focais, tive o privilégio de entrevistar velhos e velhas quilombolas, com o objetivo de registrar suas Histórias de Vida e, a partir delas, escrever a História de negros nessa parte do centrooeste do Brasil. Desde 2016 tenho usado as entrevistas gravadas como fontes para reorientar o currículo da escola Zumbi dos Palmares na Comunidade Furnas de Dionísio, ouvindo dos próprios quilombolas as temáticas que devem estruturar os trabalhos na escola da comunidade.

Utilizamos a História Oral de Vida, como procedimento básico de pesquisa para esse trabalho, conforme prática do Núcleo de História Oral da Universidade de São Paulo (NEHOUSP). A história Oral de vida, para MEIHY e RIBEIRO: 
produzidos segundo a expressão escrita, marcada por fatos notáveis da vida do entrevistado e sempre apoiada em outros suportes que não a fala ${ }^{17}$.

Esse gênero de História Oral valoriza as narrativas dos colaboradores, evitando o uso de questionários ou excessivas intervenções do entrevistador. O tempo cronológico não é marca da sequência narrativa. Grupos analfabetos, como são, na maioria, os entrevistados nessa pesquisa, desenvolvem outras soluções narrativas em função do tempo ${ }^{18}$. Possibilitamos assim que nossos entre/vistados possam desafiar a lógica do pesquisador. Para Portelli:

\begin{abstract}
“[...] a situação de entrevista institui uma bipolaridade dialógica, dois sujeitos face a face, mediados pelo emprego estratégico de um microfone. Em torno desse objeto os dois se olham. A ideia de que existe um "observado" e um "observador" é uma ilusão positivista: durante todo o tempo, enquanto o pesquisador olha para o narrador, o narrador olha para ele, a fim de entender quem é e o que quer, e de modelar seu próprio discurso a partir dessas percepções. A “entre/vista", afinal, é uma troca de olhares. E bem mais do que outras formas de arte verbal, a história oral é um gênero multivocal, resultado do trabalho comum de uma pluralidade de autores em diálogo. "19
\end{abstract}

Resumidamente são esses os motivos, para além da escassez de outras fontes, os motivos de nossa equipe recorrer à História Oral. Longe de querermos dar voz, trata-se de dar ouvidos aos nossos entrevistados para possibilitar a emergência de outras narrativas históricas. No âmbito desse artigo, recortamos diálogos das entrevistas para dar sustentação à uma narrativa acadêmica que não perdesse conexão com nossos colaboradores, mas enfatizamos que os temas e problemas emergiram das histórias de vida, devidamente autorizadas pelos entrevistados.

Fizemos entrevistas de História Oral de Vida nas comunidades de Furnas de Dionísio (município de Jaraguari), Furnas de São Sebastião da Boa Sorte (Corguinho), Furnas de São Miguel (Maracaju), Picadinha (Dourados), Tia Eva e Buritis (Campo Grande).

Para Éclea Bosi uma das principais funções sociais dos velhos é lembrar ${ }^{20}$. A memória é um trabalho exercido na comunidade de forma particular pelos mais velhos. As sociedades capitalistas são governadas por um presentismo que atende aos reclamos de consumo desenfreado como se não houvesse uma experiência passada que embasasse nossos valores. Para Maurice Halbwachs ${ }^{21}$ toda a memória é coletiva de forma que estamos seguros de que as histórias que registramos nas entrevistas vão muito além de narrações individuais, mas encerram uma experiência coletiva das respectivas comunidades. Dessa maneira cada um dos 
testemunhos sedimentados na História Oral de Vida dos membros mais velhos da comunidade são a matéria prima para a interpretação do historiador em nosso trabalho.

As comunidades negras que aportaram no sul do Mato Grosso, a partir do final do século XIX vieram com proposta distinta do colono branco para a ocupação do cerrado. Sabemos que a colonização dentro de padrões europeus de civilização, serviu/serve para atender o mercado externo, seguindo a lógica do capitalismo de desenvolvimento desigual e dependente. A erva mate e o gado foram historicamente as molas desse desenvolvimento. Sabemos bem dos resultados desse tipo de exploração: degradação do meio ambiente, exploração da mão de obra, alta concentração de renda, terras e monocultura.

Com as comunidades negras que temos analisado foi diferente. Vindos especialmente do sul de Goiás e de Minas Gerais em movimento identificado por Caio Prado Júnior ${ }^{22}$, o que conseguimos apurar, a partir das entrevistas de História Oral de Vida que fizemos nessas comunidades é que os fundadores dessas chegaram ao então sul do Mato Grosso com pecúlio próprio. Recursos modestos, provavelmente obtidos em suas terras de origem, por meio de exploração de lavouras a partir de contratos de meação ou ainda mesmo como empregados em suas de origem ou na região para onde migraram. Muitos homens empregaram-se no exército e, em que pesem os baixos soldos, temos que considerar que os gastos também eram pequenos $^{23}$, o que lhes permitiam alguma economia. Somem-se a esses fatores, as políticas de colonização na região que remontam à ocupação da área pelo Império brasileiro após a Guerra do Paraguai, passando pela "Marcha para o Oeste da Era Vargas, até a divisão do estado sob os auspícios da ditadura civil-militar (1964-85) $)^{24}$. Lembremos que as terras eram muito baratas se comparadas aos centros dinâmicos da economia de então.

As 'terras de negros' foram ocupadas de forma distinta daquelas ocupadas por gaúchos, libaneses ou japoneses. Com menos dinheiro que esses concorrentes, adquiriram terras em furnas e dedicavam-se a atividades de subsistência: plantando alimentos e criando seus animais. Entre as comunidades que pesquisamos, três delas estão localizadas em furnas $^{25}$ : Dionísio, São Sebastião da Boa Sorte e São Miguel.

Ora, esses "lugares escondidos" que serviram de abrigo a essas comunidades negras obviamente não interessavam ao projeto capitalista agrário do colono branco. A criação de gado e a monocultura deram preferência às terras de relevo não acidentado de pouca utilidade para a produção de alimentos, mas úteis para os pastos de pecuária extensiva. Carne, soja, cana-de-açúcar e, ultimamente, florestas de eucalipto têm atendido aos projetos de exportação 
muito bem representado na economia e da política brasileiras. Já as comunidades negras rurais basearam sua produção na agropecuária de subsistência e no trabalho coletivo.

Segundo Ramão Gonçalves de Souza, $65 \operatorname{anos}^{26}$ :

Minha mãe, Joaquina Gonçalves de Souza, era da fazenda Vista Alegre, aqui na região de Maracaju. Os parentes dela vieram de Minas Gerais, não sei de que lugar especificamente. Um grupo de negros se estabeleceu aqui no município de Maracaju. O lugar ficou conhecido como cabeceira preta, denominação dada pelos fazendeiros por causa da quantidade de negros na localidade. Os parentes de minha mãe eram componentes dessa caravana que aportou por aqui por volta de 1910. Ela tinha por volta de 12 anos e veio com minha avó Chica. Minha mãe sempre falava muito das tias delas que foram escravas, Josefa e Marciana tinham marcas de arreio e chicote nas costas, feitas por homens de engenho. Mencionava também tio Domingos que era chefe dos negros. Já minha mãe nasceu em 1897, depois da lei do ventre livre quando veio para cá e casou-se com meu pai. Eles se conheceram na cabeceira preta.

Para as furnas chegaram os negros repetindo a estratégia ancestral de povos africanos: buscar novas terras quando lhes era negada a possibilidade de sobrevivência digna. Foi assim com os bantus da África sul-saariana, que em processo que se iniciou a cerca de três mil anos se expandiram por quase toda África ao sul do deserto do Saara. ${ }^{27}$ Note-se que não se trata de fuga pura e simples, que pode ser interpretada como ato de covardia, como renúncia a luta. Ao contrário, trata-se de uma expansão. Toda expansão de grupos humanos pressupõe a disseminação de novos modos de vida que dizem respeito a forma de produzir, a formas de ler o mundo, enfim a uma expansão cultural e econômica.

Essa colonização negra parecia não incomodar, aparentemente, na maioria dos casos, a lógica capitalista na expansão do gaúcho, do libanês ou do japonês por essas paragens. Tratava-se de terras isoladas, de grotões que ainda assim foram usurpadas por projetos de colonização ou apossadas indevidamente. Dessa maneira, a história encomendada ou escrita pelas famílias de colonos brancos obviamente não contemplou os quilombolas e outras formas de organização dos negros no campo ou na cidade. Permanecerem enfurnados até a democratização do Estado brasileiro na década de 1980. Alijados do acesso às escolas brancas, esses negros jamais estiveram em condições de questionar a história oficial. Quando chegaram aos bancos escolares a história já estava escrita: chegaram como escravos, não possuíram terras, não tiveram produção própria, tornando-se subordinados de uma história única. Entretanto, a expansão constante do agronegócio e a organização dos negros têm acirrado os conflitos com maior ou menor intensidade a depender das relações de força entre quilombolas e fazendeiros ${ }^{28}$. 
Atualmente, identificamos outros processos que modificaram a dinâmica histórica do relacionamento dessas comunidades negras rurais com as comunidades circundantes. A primeira diz respeito a reconfiguração das forças sociais no Brasil a partir da democratização do país retomada em finais dos anos de 1970 e culminada com a constituição de 1988. A atual constituição, em suas disposições transitórias, dispõe que é dever do Estado demarcar terras de remanescentes quilombolas. Desde então, muita polêmica se seguiu para definir o que era ou deixava de ser quilombo ou quilombola. Não entrarei em detalhes sobre essa polêmica, limitando-me a dizer que essas comunidades, aliadas ao movimento negro em âmbito nacional abraçaram essa denominação como forma de regularizar a posse ou retomar terras que lhe foram usurpadas, muitas vezes ao arrepio da lei. ${ }^{29}$

$\mathrm{Na}$ atual fase de desenvolvimento da região centro oeste essa reconfiguração de identidades enseja a escrita de novas histórias, a invenção de novas tradições. Por ser um espaço relativamente recente de ocupação da fronteira agropecuária de exportação no Brasil os embates entre povos tradicionais e a modernidade assume tons dramáticos e originais. Ao lado de assassinatos de lideranças há um movimento indígena e um movimento negro fortes de grande repercussão nacional. A expansão do agronegócio tem que conviver com os avanços e recuos dos movimentos sociais e do estado democrático de direito no Brasil contemporâneo.

\section{Origem da população negra no sul do Mato Grosso: colonizadores negros e embate de projetos civilizatórios.}

Estavam, portanto, os negros chegados ao então sul do estado do Mato Grosso, no final do XIX, até meados do século XX na condição de colonizadores, tal qual os brancos vindos do sul e do sudeste, bem como gaúchos, paulistas, japoneses e libaneses que ocupam o discurso hegemônico da história da região. Em razão de uma concepção colonial de nossa História, esses negros, assim como os povos indígenas foram relegados à posição subalterna, como grupos que deveriam ser superados e incorporados à lógica da mestiçagem branqueadora que produziu seu apagamento histórico.

O embate seria entre um projeto capitalista moderno (produção para o mercado) e um projeto mais tradicional (produção para consumo interno) oriundo do sul de Goiás e de Minas Gerais e, em última instância do nordeste brasileiro.

Gilberto Freyre em sua obra mais importante cita o viajante alemão Max Schimdt que esteve no sul do estado do então Mato Grosso no início do século XX. Diferente de outros 
viajantes da época, quase sempre com os olhos voltados para as populações indígenas, Schimdt registrou os negros na região. A obra, em alemão, está no museu Barbero, em Assunção do Paraguai e constitui registro importante da presença negra no estado. Nesse trecho de sua obra, Freyre salienta que os negros importados da África para essa região dominavam técnicas de criação de gado e as teriam transmitido aos mestiços de índios com brancos ${ }^{30}$.

A disputa pelo "vazio" do centro oeste brasileiro situa-se no embate entre tradição e modernidade expresso nas formas de organização do trabalho: trabalho comunitário (as 'surpresas' relatadas em entrevista, por Seu Carlito do Quilombo de São Sebastião da Boa Sorte) e o trabalho voltado para o atendimento do mercado de produtos agrícolas e da pecuária, como é o caso do Quilombo da Picadinha, em Dourados. Nessa última, esse embate chegou ao auge no evento descrito nas quatro entrevistas que fizemos e celebrado como verdadeiro mito fundador pela comunidade: o dia em que os fazendeiros correram da polícia federal. Claro está que o patriarca fundador da comunidade da Picadinha - Seu Deziderio Felipe de Oliveira - adquiriu as terras em momento histórico de expansão para o centro oeste já no declínio da companhia Matte Larangeira. A falta de tradição em lidar com as demandas legais para a formalização da posse de terras fez que os herdeiros de Deziderio tivessem seus direitos usurpados pelos fazendeiros por meio de advogados responsáveis pelo inventário, melhores treinados nas artimanhas das leis. A maior parte das terras da comunidade foram redistribuídas por meio de venda à terceiros com a cumplicidade de cartorários e de autoridades locais.

Segundo seu Massimo, $68 \operatorname{anos}^{31}$ :

Meu avô Deziderio era de Minas Gerais da região de Uberaba, chegou em Maracajú por volta de 1890, quando tinha por volta de 20 anos. Ele foi escravo, nasceu em 1877. Ele chegou aqui trazendo boi de Minas para cá e por aqui ficou. Vieram em comitiva e trabalharam na fazenda do sitio alto que era em Vista Alegre e de lá, foram para Maracaju, onde nasceram meus pais e meus tios, os quatros primeiros. Meu pai chegou aqui, como meu avô, quando não tinha nada por essas terras. Foi o Doutor João Batista de Oliveira que demarcou a área das terras dele. Em 1926, mediram a fazenda, logo depois que meu avô participou da revolta de 1924, ele foi um dos chefes revoltosos daqui que se opôs a Prestes.

Por muito tempo, após essas usurpações, negros e negras dessas comunidades quilombolas permaneceram tratados como escravos, com especial crueldade para as mulheres como relatado na entrevista com Dona Eugênia, no quilombo São Miguel ${ }^{32}$ :

Aos 13 anos voltei para casa da mamãe. Ela me chamou de volta porque não tinha notícias minhas. Fui trabalhar numa fazenda e fiquei grávida de um filho de 
fazendeiro. Eu não sabia fazer nada. Fiquei com a criança, criei este filho até ele se casar, minha mãe me deu apoio. Ele trabalhou na lavoura em Campo Grande, Camapuã e São Miguel. Depois trabalhou numa firma com carteira assinada e graças a regularização das terras pretende voltar aqui para trabalhar com a lavoura.

Naquele tempo mulher que não tinha marido não podia ficar no meio de moças, porque era considerada prostituta.

Arrumei marido e depois me separei, continuei trabalhando em fazenda com minhas crianças. Trabalhei muito.

Outro tema constante nas entrevistas é o deslocamento das famílias do campo para a cidade em busca de melhores condições de vida e atraídos pelo desenvolvimento urbano. Esse movimento inverte-se em 2011, quando o INCRA foi imitido na posse de área para a comunidade quilombola Chácara Buriti. Seu Otacílio, repetidas vezes, falou que a família dele "trabalhava para os outros", como ocorreu em entrevistas feitas em quase todas as comunidades.

Importante notar a redução da condição de proprietários para empregados, expropriados da terra. Os entrevistados dizem ter sofrido muito na roça (pela falta de recursos para explorar a terra) e a experiência na cidade também não traz boas recordações.

Para seu Otacílio, $88 \operatorname{anos}^{33}$ :

No passado havia reunião de pessoas para limpar a lavoura do outro. Quando a lavoura estava no mato eles se reuniam e limpavam tudinho. Eles eram unidos. Naquele tempo cada um tinha sua roça. João Vida, meu sogro era quem organizava essas empreitadas porque se o mato tomasse conta das plantas não haveria mantimento. Todos obedeciam ao mais velho. Quando acabavam a limpeza alguns iam para a olaria e outros iam fazer carvão. Havia uma carvoaria com aquele fogo grande de queimar tijolos. Cortava-se madeira lá no cerrado que era puxada por carreta de boi e se queimava para fazer carvão.

Eu trabalhei na carvoaria por dois anos, por pouco tempo. Era serviço ruim, o calorão do fogo e muito pó de carvão. Pior que trabalhar em lavoura. Mas não tinha outro jeito, para ganhar um dinheiro tinha que enfrentar.

Foi depois disso que eu fui trabalhar para a lavoura do japonês, no Bom Fim em Jaguariúna onde ele morava. Era bom para trabalhar. Eu morava na colônia deles cerca de seis quilômetros de patrimônio. $\mathrm{O}$ japonês era muito carrasco. $\mathrm{O}$ sistema deles é outro, não é que nem nós brasileiros, trabalhava-se de segunda a domingo, não tinha feriado nem descanso. Aos domingos se trabalhava até o meio dia. Se chovesse havia um balcão onde ficávamos descascando milho. A chuva parava íamos para a roça. Por isso não quis ficar lá. Trabalhava quem nem escravo e decidi que não iria ficar escravo de japonês que, apesar de bom, era muito duro. Acho que no Japão deve ser assim. Deus me livre, me pergunto como é no Japão.

Outra questão importante identificada nas entrevistas e nas visitas às comunidades foi constatar que a sociabilidade em torno do catolicismo popular manteve as comunidades unidas, enquanto isoladas. Desassistidas pelo clero católico, mantiveram a reza do terço e as festas de São Sebastião como formas de confraternização. 
Os bailes promovidos em memória dos santos católicos foram importantes momentos de socialização nas comunidades. A conversão a Igrejas evangélicas provocou interdições às danças e à música, consideradas profanas e mudaram o cenário de interação comunitária. $\mathrm{O}$ catolicismo permitiu formas coletivas de associação, posteriormente substituídas por uma visão mais individualizada das igrejas evangélicas, sobretudo em São Miguel, Picadinha e Buritis.

Ao mesmo tempo, os encontros promovidos no âmbito das igrejas evangélicas, ensejam novas formas de interação comunitária: afastam o alcoolismo, promovem o trabalho individual e a autonomia das comunidades. A sacralização do espaço não depende de uma autoridade externa, como a dos padres e bispos católicos. Os pastores evangélicos são membros das comunidades investidos de poder pelas novas igrejas e tem seu poder legitimado pela comunidade e acabam investidos por um poder espiritual menos hierárquico e externo que o católico. Investigar a apropriação do discurso e das práticas de igrejas evangélicas será o próximo passo de nossa investigação.

Para Oraide, moradora da comunidade São Miguel, a transição para o evangelismo foi marcada por tensões e, ainda guarda sequelas. Em entrevista feita com Luana Aparecida Muniz, minha aluna de iniciação científica, podemos ver isso:

A minha avó era uma pessoa muito católica, portanto todos os cultos realizados eram feitos na casa dela, as festas de final de ano, a semana santa, era tudo muito respeitado por ela. Lembro-me que quando chegava a época da semana santa a gente guardava aqueles dias, pois era a época em que não podia nem ao menos se pentear o cabelo, sendo este o período da quaresma, a minha avó também gostava muito de festejar São Sebastião que se celebrava no mês de Janeiro, costumava ser um período em que todos os parentes se reuniam, aconteciam muitas brincadeiras, baile, churrascos, a minha avó nesta época gostava muito de preparar o vinho caseiro, feito com uva e de jatobá, e aquela bebida era servido nas festas, nesta época aconteciam muitas outras festas.

No entanto, quando começou a entrar outra concepção religiosa na comunidade, ou seja, a evangélica, que veio através do meu tio Ramão que começou a trazer a palavra, dando início aos primeiros cultos, portanto a transformação religiosa da comunidade se iniciou com ele que nos falava que tínhamos que mudar a nossa religião para que pudéssemos servir um Deus verdadeiro, porque a nossa religião, segundo ele, a crença nos santos católicos era coisas de barro feitas pelo homem, portanto, tínhamos que mudar para podermos crer num Deus vivo e verdadeiro.

Eu me lembro que no início, quando ele começou a trazer a palavra, muitas pessoas não aceitavam, mas com o tempo foram aceitando, e passando a ser evangélico, e aos poucos foram abrindo mão de suas crenças católicas, pois uma religião não permite a outra.

Lembro que quando a minha avó era viva os primeiros cultos foram feitos na casa dela, debaixo dos pés de manga, e lá tinha alguns bancos, onde a gente cantava. Tio Ramão fazia oração ali naquele local e realizávamos os cultos, era um tempo muito bom, pois as lembranças que eu tenho dela são muito boas. 
No começo foi muito difícil deixar de lado aquela cultura que nós tínhamos, pois, o pessoal usava muito cultuar os santos católicos, portanto foi necessário jogar ou então levar aquele santo para alguma igreja, pois eu não sei se eles jogaram fora ou se levaram para alguma igreja, mas me recordo que foi um momento muito doloroso para minha mãe, para minha avó e para todos da comunidade, pois todos nasceram naquela crença religiosa, portanto não foi nada fácil ${ }^{34}$.

\section{Processos de (re)definição identitária na reivindicação de direitos junto ao Estado}

Como nos ensinam Arruti (2006) e Santos (2003), os termos quilombo e quilombola passaram (passam) por um processo de ressemantização.

O Instituto Histórico e Geográfico Brasileiros de Mato Grosso do Sul (IHGB/MS) apresentou parecer em 2008, baseado em pretensa documentação histórica, afirmando não existir quilombos ou remanescentes dos mesmos no estado, considerando que a região não esteve envolvida nos ciclos econômicos que usaram o escravismo como modo de produção. A colonização efetiva do estado, posterior a esses ciclos, teria livrado a região da escravidão, tendo a mesma sido insignificante e, quando muito, ocorrida quando o processo de emancipação dos escravos, já ia bem adiantado no Brasil.

Parecer Quilombolas.

"Os associados efetivos do Instituto Histórico e Geográfico de Mato Grosso do Sul, Considerando que o sul de Mato Grosso despontou no cenário econômico brasileiro como área de produção pecuária, após as décadas de 1830/1840, quando a escravidão já se encontrava em processo gradativo de desarticulação; Considerando que o território hoje sul-mato-grossense se encontrava fora da rota de fuga dos escravos egressos dos centros econômicos mais significativos à época do regime escravista (SP, MG e região norte de MT); Considerando que havia, no último quartel do século XIX, forte empenho de líderes pela libertação de escravos, a exemplo das Juntas de Emancipação nas principais vilas e cidades do sul de Mato Grosso, com resultados positivos; Considerando que, sobretudo após a Guerra da Tríplice Aliança, o número de escravos no sul de Mato Grosso era de reduzido significado; Considerando que não há documentos, nem ao menos indícios, que provem a existência, no atual Mato Grosso do Sul, de quilombos, mesmo que tardios. Manifestam-se, por unanimidade, no sentido de não reconhecer a presença de quaisquer núcleos quilombolas remanescentes em nosso Estado. Campo Grande, 10 de setembrode 2008. Hildebrando Campestrini, Presidente". 35

O critério é obviamente arqueológico e age com a definição - negativa - que o colonizador atribuiu à expressão 'quilombo'. De qualquer maneira, cabem ainda investigações ao redor da possibilidade de escravos fugitivos a caminho da Bolívia e do Paraguai (países que aboliram a escravidão antes do Brasil) terem criado comunidades em terras hoje conhecidas como Mato Grosso e Mato Grosso do Sul, tal como registramos em entrevistas na 
Comunidade de Furnas de Boa Sorte que relacionam a presença de negros na região com a Guerra do Paraguai.

Arruti debate a ressemantização do termo "remanescentes de quilombos", acompanhando Sansone no conceito de etnização ao invés de etnicidade ${ }^{36}$.

A identificação de indivíduos e de grupos estaria muito mais ligada à um processo do que a uma 'origem' ancestral fixada no tempo e no espaço. Manuela Carneiro da Cunha demonstrou isso muito bem, décadas atrás, ao analisar a identificação dos iorubas em diferentes contextos na África e no Brasil, passando-se por católicos, muçulmanos, protestantes ou candomblecistas, conforme suas necessidades econômicas e políticas de momento ${ }^{37}$.

Para Sansone, os processos de criação de identidades étnicas devem ser entendidos no contexto da globalização que causam um movimento paradoxal: ao mesmo tempo em que nunca se falou tanto em identidade e etnicidade, nunca as formas de expressar diferenças foram tão parecidas. É como se existissem, a disposição no mercado global, diferentes formas e símbolos disponíveis de identificação, prontos para serem incorporados e acionados quando for conveniente para esses grupos ${ }^{38}$.

Nas comunidades negras em Mato Grosso do Sul, encontramos um embate político de projetos em esferas globais, nacionais e locais. Na instância global ocorre o acionamento de afirmação de identidades, onde o clamor pelo direito às diferenças serve muitas vezes mais como 'slogan' para venda de mercadorias, do que, propriamente para conquista de direitos. No cenário nacional brasileiro temos um forte movimento questionador de nossa identidade mestiça por parte de grupos organizados nos movimentos negros (para não falar dos indígenas) e, ao mesmo tempo, permanece a forte crença popular no mito da miscigenação.

Como nos lembra Sansone, a identificação racial ou étnica nunca foi suficiente para mobilizar brasileiros na busca por seus direitos. Essa mudança de perspectiva alterou a agenda da produção intelectual brasileira, que de legitimadores da unidade nacional, passamos a "porta vozes" dos direitos das minorias.

As comunidades até aqui analisadas foram constituídas nas franjas da civilização branca europeia, em terras outrora fora da dinâmica do processo capitalista. Na medida em que as demandas por alimentos (pecuária e agricultura) dos grandes centros empurraram o projeto modernizador para essas paragens, essas comunidades saíram do seu isolamento e se veem diante do desafio de se diferenciarem para sobreviver. Lá onde morre a comunidade, nasce a identidade ${ }^{39}$. A demanda da construção da identidade não é própria das comunidades 
tradicionais. É externa as mesmas. Vem dos processos da globalização em suas instâncias econômicas, políticas e culturais.

As comunidades negras rurais de Mato Grosso do Sul, agora (re)definidas "quilombolas" devem sair do lugar onde viviam "enfurnadas" e disputar com outros grupos suas possibilidades de existência. Assumir uma identidade étnica ou cultural significa habilitar-se para competir por recursos em agências nacionais e internacionais de fomento ao desenvolvimento. Essa condição foi criada com o evento da globalização ou modernidade tardia, fragmentando e deslocando identidades culturais de classe, gênero, etnia, raça e nacionalidade. ${ }^{40}$ Acreditamos que por meio da História Oral de Vida possamos contribuir para o entendimento do processo de redefinição identitária desses negros e de como os mesmos situam suas demandas diante dos interesses de outros grupos e da curiosidade de nós, intelectuais, possibilitando o estabelecimento de outras narrativas históricas.

\section{Notas}

\footnotetext{
${ }^{1}$ Ato das Disposições Constitucionais Transitórias (ADCT): Art. 68. Aos remanescentes das comunidades dos quilombos que estejam ocupando suas terras é reconhecida a propriedade definitiva, devendo o Estado emitirlhes os títulos respectivos.

${ }^{2}$ NASCIMENTO, Abdias do. O Quilombismo: Documentos de uma militância pan-africanista. Petrópolis: Vozes, 1980. O livro reúne ensaios escritos em diferentes épocas no Brasil e nos Estados Unidos e se propõe a cobrir a ausência de uma escrita da história dos negros brasileiros, pelos próprios negros. Destaque-se o Documento $n^{o}$ 7: Quilombismo: um conceito científico emergente no processo histórico-cultural das massas afro-brasileiras. pp.245-280.

Saliente-se que já em maio de 1949 na revista Quilombo Abdias do Nascimento já chamava atenção para a "bravura indomável dos próprios escravos" que no processo de abolição, "liquidaram” o regime escravista "antes de [ele] ser derrogado por lei. (Cf. SLENES, Robert W. na apresentação do livro de GOMES, Flávio dos Santos. A Hidra e os pântanos: quilombos e comunidades de fugitivos no Brasil. (Séculos XVII-XIX). São Paulo: Ed. UNESP: Ed. Polis, 2005, p. 18.)

${ }^{3}$ GOMES, Flávio dos Santos. Histórias de Quilombolas: Mocambos e comunidades de senzalas no Rio de Janeiro, século XIX. São Paulo: Companhia das Letras, 2006. p. 8. João José dos Reis na segunda orelha do livro refere-se a Gomes como ocupante da "... posição de principal especialista em quilombos no Brasil”.

${ }^{4}$ GOMES, 2006. p. 9.

${ }^{5}$ Idem, p. 10.

${ }^{6}$ Idem, p. 12 .

${ }^{7}$ Idem, p. 13 .

${ }^{8}$ GOULART, José Alípio. Da fuga ao suicídio. Aspectos da rebeldia dos escravos no Brasil. Rio de Janeiro, Conquista, 1972. Apud GOMES, Op. Cit.

${ }^{9}$ FREITAS, Décio. Palmares, a guerra dos escravos. Porto Alegre, Movimento, 1976 e Insurreições escravas, Porto Alegre, Movimento, 1976. Apud GOMES, Op. Cit.

${ }^{10}$ Esse termo é usado com frequência por Flávio dos Santos Gomes e enfatiza a circularidade das relações entre cativos e quilombolas além de outros setores da sociedade envolvente: taberneiros, libertos, homens livres pobres, camponeses, regatões e indígenas. GOMES, 2005, p. 37.

${ }^{11}$ GOMES, 2006. pp. 18-19.

${ }^{12}$ Idem, p. 21.

${ }^{13}$ GOMES, 2005. p. 26.

${ }^{14}$ GINZBURG, Carlo. Sinais: raízes de um paradigma indiciário. In: Mitos, emblemas, sinais. Morfologia e História. São Paulo: Companhia das Letras, 1989, pp. 143-180.

${ }^{15}$ GOMES, 2006, p. 34.
} 
16 Projeto financiado pela Fundação de Apoio ao Desenvolvimento da Educação, Ciência e Tecnologia (FUNDECT-MS) do estado do Mato Grosso do Sul por meio do edital 12/2012 e coordenado pelo Prof. Dr. Antônio Hilário Urquiza.

${ }^{17}$ MEIHY, José Carlos Sebe Bom \& RIBEIRO, Suzana Lopes Salgado. Guia Prático de História Oral para empresas, universidades, comunidades, famílias. São Paulo: Ed. Contexto, 2011. p.82.

${ }^{18}$ MEIHY \& RIBERITO, Op. Cit. p. 83.

${ }^{19}$ PORTELLI, Alessandro. Ensaios de História Oral. São Paulo, Letras e Voz, 2010. p. 20.

${ }^{20}$ BOSI, Éclea. Memória e Sociedade: lembrança de velhos. São Paulo: Cia das Letras, 2004.

${ }^{21}$ HALBWACHS, Maurice. A Memória Coletiva. São Paulo: Centauro, 2004.

${ }^{22}$ PRADO JUNIOR, Caio. História Econômica do Brasil. São Paulo: Brasiliense, 2004 [1945]. pp. 203-204.

${ }^{23}$ Entrevista com Mássimo de Oliveira, em 20 de maio de 2011.

${ }^{24}$ Uma das principais molas da interiorização para a região centro-oeste foi a necessidade de transferência da capital para o interior. A questão da segurança nacional era o principal motivo apresentado pelos defensores da ideia. De fato, as duas guerras mundiais impulsionaram o projeto. A expedição "Roncador-Xingu" marcou a efetivação do mesmo. Confira: VILLAS BOAS, Orlando e Cláudio. A Marcha para o Oeste: a epopeia da Expedição Roncador-Xingu. São Paulo: Companhia das Letras, 2012. [1943-44]. pp.33-34.

As políticas de ocupação do extremo sul do antigo Mato Grosso obedeceram às razões de segurança de fronteiras brasileiras. Após a Guerra do Paraguai (1864-70), grandes porções do território foram arrendadas à Companhia Matte Laranjeira, por decreto imperial em 1882. A empresa foi responsável pela extrema exploração da mão de obra de kaiowas e guaranis na região (frequentemente identificados como "paraguaios"). Seu faturamento chegou a corresponder a seis vezes o orçamento do antigo estado do Mato Grosso, a quem a companhia emprestou dinheiro diversas vezes, no auge de sua produção, no início do século XX. Seu monopólio só foi quebrado em 1916. Em 1943, o Estado Novo decidiu tirar da companhia e de outros particulares a ocupação das terras da região, criando o território federal de Ponta-Porã, alegando razões de segurança nacional na fronteira. Foi quando o Estado brasileiro arrendou terras devolutas na região, por meio da criação da colônia agrícola de Dourados (C.N.A) dando origem ao primeiro projeto bem-sucedido de colonização encetado pelo Estado. Depois disso outros projetos são implantados impulsionado a fronteira agropecuária na região. Confira: ALBANEZ, Jocimar Lomba. Ervais em Queda: Transformações no Campo no Extremo-Sul de Mato Grosso (19401970). Dourados-MS: Ed. UFGD, 2013.pp. 69-75. A aristocracia que usurpou terras de povos tradicionais chegou ao auge com a divisão do estado em 1974, dando origem ao Mato Grosso do Sul.

${ }^{25}$ As definições para o termo "furna" não são positivas, no dicionário Houaiss [HOUAISS, 2013] encontramos as seguinte definições para o termo: “ Furna: substantivo feminino ( $s X V) ; 1$ cavidade profunda na encosta de uma rocha, floresta etc.; caverna, gruta, cova «o homem primitivo transformava f. em habitações grupais >; 2 p.ext. subterrâneo de uma edificação; 3 p.ext. B N.E. lugar isolado, escondido, escuro; 4 PR m.q. carijó; Etimologia

prov. alt. de forno com mudança de gênero, por infl. do lat. fürnus ou fōrnus, i 'forno'; ver forn- Sinônímia e Variantes:algar, aljube, antro, buraco-soturno, brugueia, carijo, caverna, cova, covil, cripta, espelunca, fojo, forjoco, grota, grotão, grotião, grotilhão, gruna, gruta, grutião, grutilhão, itaoca, lapa, lapão, refojo, socairo, socava, socavão, solapa, solapão, soroca."

${ }^{26}$ As entrevistas concedidas com seu Ramão, atual patriarca da comunidade, começaram em maio de 2011. A versão final foi autorizada em agosto de 2014.

${ }^{27}$ O mapa linguístico da África estabelecido por Greenberg mostra que mais de $80 \%$ das línguas africanas hoje existente originaram-se próximas da região do Sahel, o que indica uma possível ocupação do continente a partir de populações que habitavam a região. As causas e as modalidades dessa expansão só podem ser objetos de especulação, mas são consensuais entre especialistas de história da África. Foi ao redor das línguas bantu que tivemos o maior número de contribuições de estudiosos. São falantes dessas línguas a maioria dos escravizados trazidos ao Brasil. Confira: M’BOKOLO, Elikia. África Negras: História e Civilizações. Tomo I (até o século XVIII). Salvador: EDUFBA; São Paulo: Casa das Áfricas, 2009, pp. 71-75.

${ }^{28}$ No Mato Grosso do Sul, temos o conflito de terras mais violento entre fazendeiros e quilombolas da Comunidade da Picadinha. A questão já se arrasta por décadas, envolvendo inclusive ameaça de morte aos líderes quilombolas e hostilidades contra funcionários do INCRA e antropólogos, por parte dos grandes proprietários de terra, na cidade de Dourados.

29 O antropólogo José Maurício Arruti produziu exaustivo estudo a respeito do que ele chama de "ressemantização" do termo "quilombo". Seus estudos mostram as diferenças entre as definições utilizadas nos trabalhos de historiadores e antropólogos para o termo. Segundo Arruti, para os primeiros, prevaleceria o termo 'arqueológico' que tem sua origem na legislação de autoridades coloniais e imperiais que classificavam os quilombos como lugares de negros "fugidos" contingentes ao sistema escravista. Entre os antropólogos a expressão teria substituído o termo "comunidades negras rurais". Essa mudança ocorreu a partir do artigo 68 da 
ADCT e manteve o critério de definição por meio da autodeclaração, tal como para os povos indígenas. Em função de nossa pesquisa assentar-se em uma História do Tempo Presente, preferimos à definição antropológica que é, correntemente, a utilizada por nossos entrevistados. Confira: ARRUTI, José Maurício. Mocambo: Antropologia e História do processo de formação quilombola. Bauru: EDUSC, 2006, em particular pp. 55-97.

${ }^{30}$ Segundo Freyre: “[...] E Max Schimdt destaca dois aspectos da colonização africana que deixam entrever superioridade técnica do negro sobre o indígena e até sobre o branco: o trabalho de metais e a criação de gado $[\ldots]$

Schimdt observou em Mato Grosso que muitas das práticas ligadas à criação de gado eram de origem africana. Também os instrumentos de ferreiro. Teriam sido transmitidos aos mestiços de índios com brancos pelos escravos negros. Confira: FREYRE, Gilberto. Casa Grande \& Senzala: Introdução à história da sociedade patriarcal no Brasil. Rio de Janeiro: São Paulo: Record, 2000 [1933]. pp. 364-365.

${ }^{31}$ Entrevista com Mássimo de Oliveira, em 20 de maio de 2011.

${ }^{32}$ Entrevista com Dona Eugênia Gonçalves de Souza, em 24 de setembro de 2011.

${ }^{33}$ Entrevista com Otacílio Bento de Arruda, em maio de 2011.

${ }^{34}$ Entrevista com Oraide Gonçalves Pacheco feita por Luana Aparecida Muniz em agosto de 2014.

${ }^{35}$ SANTOS, Carlos Alexandre Barboza Plínio dos. Fiéis-Descendentes: Redes-Irmandades na pós-abolição entre as comunidades negras rurais sul-mato-grossenses. Brasília, Unb. Tese de Doutorado, 2010. pp. $20-21$.

${ }^{36}$ Segundo Lívio Sansone: "O caso do Brasil demonstra com muita ênfase que a identidade étnica é um construto social de caráter contingente e que difere de um contexto para outro. [...]. Se a identidade étnica não é entendida como essencial, é preciso concebê-la como um processo, afetado pela história e pelas circunstâncias contemporâneas e tanto pela dinâmica local quanto pela global A identidade étnica pode ser considerada como um recurso cujo poder depende do contexto nacional ou regional. Ela é, portanto, uma história sem fim. Talvez devêssemos usar o termo "etnização", em vez de etnicidade (grifos meus) como foi sugerido por Frigerio (2000), que enfatiza estarmos lidando mais com uma dinâmica do que com uma entidade (ao contrário do uso do termo etnicidade no sentido de origem, como se vê, por exemplo, na maneira como ele é usado pelo US. Census Bureau - Instituto de Recenseamento dos Estados Unidos). SANSONE, Lívio. Negritude sem Etnicidade: O local e o global nas relações raciais e na produção cultura negra do Brasil. Salvador: EDUFBA; Pallas, 2003. p.12.

Da mesma forma, J.M. Arruti afirma que a definição contemporânea de Quilombo atravessa critérios históricos, antropológicos e jurídicos a partir do artigo 68 das Disposições Transitórias da Constituição de 1988. A ressemantização do termo defendido pela Associação Brasileira de Antropologia (ABA) em 1994, obedeceria, para o autor, à definição de três paradigmas: "remanescentes", "terras de uso comum" e "etnicidade" [ARRUTI, Op. Cit. pp.79-87]. O termo "remanescentes" surgiu, na escrita do legislador, para resolver a difícil relação de continuidade e descontinuidade com o processo histórico, em que a descendência não parecer ser um laço suficiente [Idem p. 81] As terras de uso comum deslocariam a identidade desses grupos para a temática atual do conflito fundiário que permitiu que o movimento negro rural se reapropriasse da categoria quilombola [Idem, $\mathrm{p}$. 91]. Por último o paradigma da etnicidade colocaria a dinâmica das redefinições identitárias, confrontando o critério da autodeclaração, com a adesão ao rótulo jurídico demandado pelo "artigo 68" que reclamaria critérios externos objetivos para a demarcação de terras pelos agentes do Estado (Fundação Palmares e INCRA) que exigiria a demarcação de um "etnicidade" contrastando com a dinâmica da etnização.

${ }^{37}$ CUNHA, Manuela Carneiro da. Religião, comércio e etnicidade: uma interpretação preliminar do catolicismo brasileiros em Lagos no século XX. In: Antropologia no Brasil: mito, história, etnicidade. São Paulo: Brasiliense: Editora da Universidade de São Paulo, 1986.

${ }^{38}$ SANSONE. Op. Cit. p. 14.

${ }^{39}$ BAUMAN, Zygmunt. Comunidade: a busca por segurança no mundo atual. Rio de Janeiro: Jorge Zahar ed, 2003. O autor trabalha com o conceito de "modernidade líquida" para enfatizar a volatilidade das relações nas sociedade pós-modernas. Define a comunidade tradicional como espaço onde as identidades eram sólidas e inquestionáveis elegendo como principais modelos: a Igreja, a vizinhança e a família, todas em crise atualmente. No local dessas comunidades onde "todos se conheciam" emergem as necessidades de filiações provisórias às comunidades modernas, onde os pactos internos e com outras comunidades são, a toda hora, renegociados, gerando a sensação de insegurança que vivemos no mundo contemporâneo e provocando a necessidade de redefinições identitárias para a conquista de direitos junto ao Estado liberal.

${ }^{40}$ Sobre identidade cultural na pós-modernidade, além de Zygmunt Bauman, já citado, confira também: HALL, Stuart. Identidade cultural na pós-modernidade. Rio de Janeiro: DP\&A, 2006 e Da Diáspora: Identidades e Mediações Culturais. Belo Horizonte: Editora UFMG, 2009. 
Referências bibliográficas:

ALBANEZ, Jocimar Lomba. Ervais em Queda: Transformações no Campo no ExtremoSul de Mato Grosso (1940-1970). Dourados-MS: Ed. UFGD, 2013.

ARRUTI, José Maurício. Mocambo: Antropologia e História do processo de formação quilombola. Bauru: EDUSC, 2006.

BASTIDE, Roger. As Américas negras: as civilizações africanas no Novo Mundo. São Paulo: Difel, 1974.

BAUMAN, Zygmunt. Comunidade: a busca por segurança no mundo atual. Rio de Janeiro: Jorge Zahar ed, 2003.

ed, 2005.

Identidade: entrevista a Benedetto Vecchi. Rio de Janeiro: Jorge Zahar

BORGES, Maria Celma Escravos, roceiros e povos originários em Sant' Ana de Paranaíba: terra e liberdade nos campos do sul de Mato Grosso (séculos XVIII e XIX). Revista Mundos do Trabalho, v. 4, p. 45-67, 2012.

BOSI, Éclea. Memória e Sociedade: lembrança de velhos. São Paulo: Cia das Letras, 2004.[1979]

CARNEIRO, Edison. O Quilombo dos Palmares. São Paulo: Editora WMF Martins Fontes, 2011. Apud GOMES, 2006.

CUNHA, Manuela Carneiro da. Religião, comércio e etnicidade: uma interpretação preliminar do catolicismo brasileiros em Lagos no século XX. In: Antropologia no Brasil: mito, história, etnicidade. São Paulo: Brasiliense: Editora da Universidade de São Paulo, 1986.

FERNANDES Florestan. O negro no mundo dos brancos. São Paulo: Global Editora, 2007 [1972].

FREYRE, Gilberto. Casa Grande \& Senzala: Introdução à história da sociedade patriarcal no Brasil. Rio de Janeiro: São Paulo: Record, 2000 [1933]

FRIGERIO, Alejandro. Cultura negra em el Cono Sur: representaciones em conflito. Buenos Aires: Ediciones de la Universidad Catolica de Argentina, 1989.

GOMES, Flávio dos Santos. Histórias de Quilombolas: Mocambos e comunidades de senzalas no Rio de Janeiro, século XIX. São Paulo: Companhia das Letras, 2006[1996].

. A Hidra e os pântanos: quilombos e comunidades de fugitivos no Brasil. (Séculos XVII-XIX). São Paulo: Ed. UNESP: Ed. Polis, 2005.

GOULART, José Alípio. Da fuga ao suicídio(aspectos de rebeldia escrava no Brasil). Rio de Janeiro: Conquista, 1972.

GUIMARÃES, Antônio Sérgio Alfredo. "Intelectuais negros e formas de integração nacional in: Estudos Avançados. Universidade de São Paulo. Instituto de Estudos Avançados. Vol. 18, $\mathrm{n}^{\mathrm{o}}$ 50, janeiro/abril de 2004. pp.271-284.

GUIMARÃES, Bernardo. Lendas e Romances. Rio de Janeiro: B.L. Garnier, 1871. Apud GOMES, 2006.

HALBWACHS, Maurice. A Memória Coletiva. São Paulo: Centauro, 2004.

HALL, Stuart. Identidade cultural na pós-modernidade. Rio de Janeiro: DP\&A, 2006.

UFMG, 2009.

Da Diáspora: Identidades e Mediações Culturais. Belo Horizonte: Editora

HOUAISS, Antônio \& VILLAR, Mauro de Salles. Grande Dicionário da Língua Portuguesa, versão eletrônica em http://houaiss.uol.com.br/, acessado em 22 de novembro de 2017. 
LUNA, Luís. O negro na aluta contra a escravidão. Rio de Janeiro: Leitura, 1968. Apud GOMES, 2006.

M'BOKOLO, Elikia. África Negras: História e Civilizações. Tomo I (até o século XVIII). Salvador: EDUFBA; São Paulo: Casa das Áfricas, 2009

MEIHY, José Carlos Sebe Bom \& RIBEIRO, Suzana Lopes Salgado. Guia Prático de História Oral para empresas, universidades, comunidades, famílias. São Paulo: Ed. Contexto, 2011.

MOURA, Clóvis. Rebeliões da Senzala (quilombos, insurreições, guerrilhas). São Paulo: Zumbi, 1959. Apud GOMES, 2006.

NOGUEIRA, Oracy; "Preconceito de marca e preconceito racial de origem (sugestão de um quadro de referência para a interpretação do material sobre relações raciais no Brasil) " in: Tanto preto quanto branco: estudos de relações raciais.

São Paulo: T.A. Queiroz, 1985, pp.67-93.

PORTELLI, Alessandro. Ensaios de História Oral. São Paulo, Letras e Voz, 2010.

PRADO JUNIOR, Caio. História Econômica do Brasil. São Paulo: Brasiliense, 2004 [1945].

SANSONE, Lívio. Negritude sem Etnicidade: O local e o global nas relações raciais e na produção cultura negra do Brasil. Salvador: EDUFBA; Pallas, 2003.

SANTOS, Carlos Alexandre Barboza Plínio dos. Fiéis-Descendentes: Redes-Irmandades na pós-abolição entre as comunidades negras rurais sul-mato-grossenses. Brasília, Unb. Tese de Doutorado, 2010.

VILLAS BOAS, Orlando e Cláudio. A Marcha para o Oeste: a epopeia da Expedição Roncador-Xingu. São Paulo: Companhia das Letras, 2012. [1943-44] 